\title{
PRODUCTION PATTERN OF MILK: A STUDY AT KMF
}

\author{
${ }^{1}$ Geetha M. Rajaram
}

\section{Introduction}

India has emerged today as the largest producer of milk in the world crossing 100 million tonnes of annual milk production. The credit for which largely goes to Operation Flood that linked millions of smallholder producers to urban consumers. The success of Indian dairy industry was possible because of the cooperative structure and the White revolution. The White revolution has transformed dairy industry in India - it increased the availability of milk as well as provided a reliable source of income and employment to millions.

However, the key problems facing the dairy industry in India are its milk productivity and lack of quality control and monitoring mechanisms across the supply chain. About 35 percent of milk produced in India is processed. The organised sector processes about 13 million tonnes annually, while the unorganised sector processes about 22 million tonnes of milk per annum. Hence there is a huge potential for the processing and value addition in this sector. In the new era of liberalization and privatization, when there is a surge of private dairy farms, there is a cut throat competition in the market. Considering this, efficient management of milk unions under cooperative sector must be given due importance. Therefore there is an urgent need to appraise the activities of dairy milk unions, especially those under the cooperative sector.

Today, milk processing has emerged as a major industrial activity in the country. During the last few years, liquid milk marketing by dairy cooperatives has been growing at around 4 per cent on a low base while milk procurement has been growing between 7-9 per cent on a higher base. Though district cooperatives have been selling 80 per cent of their procurement as liquid milk, the gap between milk produced and liquid milk marketed is growing significantly. If the current trend continues, the dairy cooperatives would be selling lesser proportion of the procured milk in liquid form. Such a situation would subject the district cooperatives and consequently their members to high risk. Therefore an attempt is made to determine the milk productivity of India and Karnataka with special reference to the milk unions under Karnataka Milk Federation over a period of five years.

\section{Milk Production in India}

The world dairy is zooming in on India for its rapidly UP Ofolowing markets. The change in the international 4 dain trade pattern and World trade organisation (5is)) offer to the Indian dairy industry an opportunity to take its due place as an exporter. The GaL Indian dairy industry is in a period of rapid change, VE $\triangle$ which is affecting the profitability and competitiveness of dairy farmers. Current restructuring of the dairy industry has been accelerated by many factors including new technologies, improved management skills, changing milk pricing schemes, processor consolidation, and shifts in consumer demand. These factors have caused many dairy farm businesses to make adjustments in order to remain competitive and viable.

Today India has emerged as the largest milk producer in the world with more than 100 million tonnes of annual milk production. According to the NSSO, National Statistical Survey Organisation, total milk production and per capita availability of milk increased as shown in Table 1 below.

1 Geetha M. Rajaram,

Asst. Professor - REVE Institute of Technology \& Management,

Kattigenahalli, Yelahanka, Bangalore 
Table 1

Milk production and per capita availability of milk in India 2000-01 to 2006-07

\begin{tabular}{|c|c|c|}
\hline Years & Milk (In million tonnes) & Per capita availability(grams/ day) \\
\hline $2000-2001$ & 80.6 & 220 \\
\hline $2001-2002$ & 84.4 & 225 \\
\hline $2002-2003$ & 86.2 & 230 \\
\hline $2003-2004$ & 88.1 & 231 \\
\hline $2004-2005$ & 92.5 & 233 \\
\hline $2005-2006$ & 97.1 & 241 \\
\hline $2006-2007$ & 100.0 & 245 \\
\hline
\end{tabular}

Note: From 2004-05 onwards, population projected by censusindia.net is taken and approximated for a midpoint of March to Feb period by linear method.

Source: State/UT Animal Husbandry Departments. Dairy development, State wise.

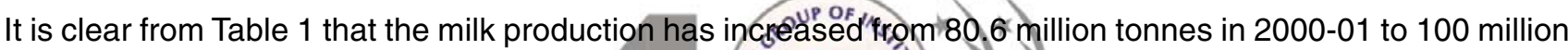
tonnes in 2006-07. The per capita availability of mille to fegistêred a growth from 220 grams per day to 245 grams per day. Milk production in India has doubled over the past two decades. However, milk procurement in different regions of India brings out important facts as showarin Table 2. Although northern part of India has contributed to the larger portion of milk production, the western region supported by the ANAND pattern procures the largest proportion of milk.

19ạblè̃2 2011

Growth in Average Milk Procurement - Region-Wise, 2004-05.

Milk Procurement Region Wise (Thousand Kilograms per day)

\begin{tabular}{|l|l|}
\hline Regions & $\mathbf{2 0 0 4 - 0 5}$ \\
\hline Northern & $3,603(18 \%)$ \\
\hline Western & $9,016(45 \%)$ \\
\hline Southern & $6,456(32 \%)$ \\
\hline Eastern & $995(5.0 \%)$ \\
\hline Total & 20,070 \\
\hline
\end{tabular}

Note: Figures in Parentheses are percentages to the total.

Source: P.R. Gupta, Dairy India, $6^{\text {th }}$ edition, New Delhi; 2007, p.116. 
The northern region constitutes the states of Haryana, Himachal Pradesh, Jammu and Kashmir, Punjab, Rajasthan, Uttar Pradesh and Delhi. Chhattisgarh, Goa, Gujarat, Madhya Pradesh, and Maharashtra constitute the western region. The southern region comprises of Andhra Pradesh, Karnataka, Kerala, Tamil Nadu and Pondicherry. The eastern region includes the states of Assam, Bihar, Jharkhand, Nagaland, Orissa, Sikkim, Tripura and West Bengal. From Table 4.3, the following observations are offered. Over the years, the share of western region in total milk procurement in the country has been dwindling from about 62 per cent to 45 per cent between 198-81 and 2004-05. Both southern and eastern regions are steadily improving their milk procurement. The improvement is more pronounced in the former than in the latter. On the other hand, northern region is not left behind; it has steadily increased its milk procurement from 12 per cent to 18 per cent during the same period. production of milk in the country. Gujarat produces nearly one crore litres of milk, while Karnataka produces 50 lakh litres of milk every day ${ }^{1}$. Karnataka possesses a large number of milch animal population but due to the low productivity of nondescript animals the growth of milk production in the state has not been satisfactory. In certain areas cattle are reared mostly for draught purpose and manure. In some districts, cattle population is more in numerical figures but they are not habituated for milk.

The Table 3 clearly reveals the wide gap between growth in milk production and per capita availability of milk in this State. This only testifies the fact that the milk production has not kept pace with the population growth. Between 1997-98 and 2006-07, the total production of milk increased from 3,970 Million tonnes to 4,599 million tonnes, in 2000-2001 by 2.86 percent; however there has been a fall in milk production in 2002-04. However the position

\section{Production Pattern of Milk in Karnataka}

up ofyas better with the annual milk production Southern region of India showed a steady improvement in the quantity of milk procured in the country. Karnataka has also been a major milk producing state and has significantly contributed to the increase in milk production and procurement in the country. Karnataka is next only to Gujarat in 971 togrowth1

\section{Table 3}

Milk production and Per Capita availability of Milk in Karnataka, 2000-2007

\begin{tabular}{|c|c|c|c|c|}
\hline Year & $\begin{array}{c}\text { Milk } \\
\text { Production(in } \\
\text { million tonnes) }\end{array}$ & $\begin{array}{c}\text { Growth rate } \\
\text { over previous year } \\
(\%)\end{array}$ & $\begin{array}{c}\text { Per capita } \\
\text { availability of } \\
\text { milk }\end{array}$ & $\begin{array}{c}\text { Growth rate over } \\
\text { previous year } \\
(\%)\end{array}$ \\
\hline $2000-2001$ & 4,599 & - & 233 & - \\
\hline $2002-2003$ & 4,539 & -1.30 & 229 & -1.71 \\
\hline $2003-2004$ & 3,857 & -15.02 & 190 & -17.3 \\
\hline $2004-2005$ & 3,917 & +1.55 & 194 & +2.10 \\
\hline $2005-2006$ & 4022 & +2.68 & 197 & +1.54 \\
\hline $2006-07$ & 4124 & +2.54 & 200 & +1.52 \\
\hline
\end{tabular}

Source: Statistical abstract of Karnataka, Directorate of Economics and Statistics, 2006-07

1 Times News Network, Times of India, Feb 11, 2010. 
The analysis of Table 3 reveals the following details. The growth of per capita availability has been far less than the growth of milk production. Secondly, the growth of milk production has shown progress in late 90 s and early 2000 . Milk production in Karnataka has been declining after the Operation Flood programme ended in 1997 till 2003-04.One of the reasons attributed for the decline was unfavourable weather conditions and increased urbanization in southern parts of Karnataka which is a major area for milk production in the state. However, milk production has increased marginally, while the per capita availability has declined. This indicates the scope for increasing the milk production in the State of Karnataka.

\section{Procurement and Sale of Milk in Karnataka}

The procurement and sale of milk are two important aspects of marketing of milk which makes the activity of dairying more profitable to the milk producers. Proper marketing is necessary for milk and milk products because of their perishable nature. It also acts a catalyst for rapid development of dairy activity. But procurement and sale of milk depends up on the infrastructure and market network more so in the rural areas from where most of the milk production comes.

Not the entire production of milk procured is sold; a portion of the total milk production is retained for own use. Secondly most of the milk produced is sold in the unorganized market. This is true in Karnataka also. Table 4 shows procurement and sales of milk since 2003-04 to 2006-07.

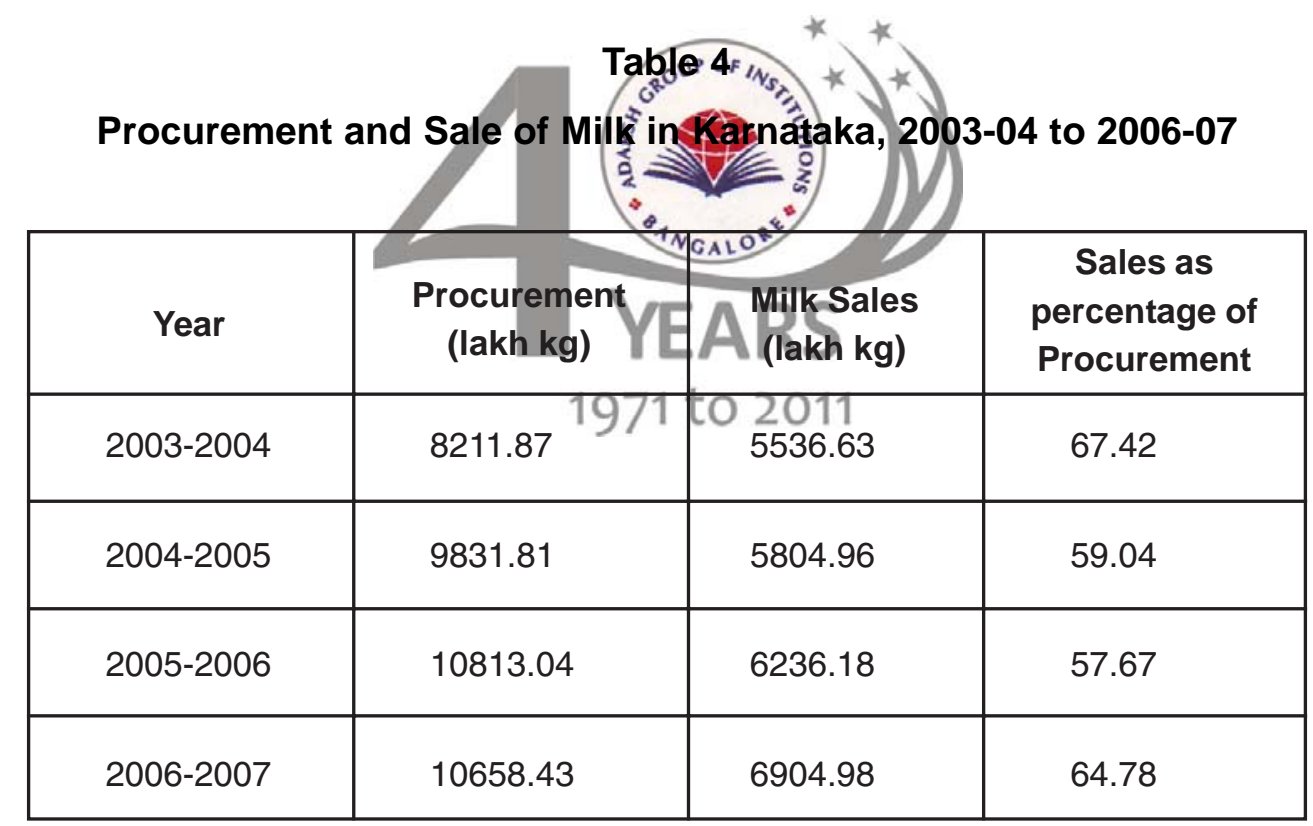

Source: Statistical abstract of Karnataka, Directorate of Economics and Statistics, 2006-07

It could be seen from Table 4 that the procurement of milk in Karnataka increased from 8211.87 lakh kilograms in 2003-2004 to a staggering level of 10658.43 lakh kilograms in 2006-07. The sales also increased from 5536.63 lakh kilograms in 2003-2004 to 6904.98 lakh kilograms in 2006-07. The percentages of milk sold to procured milk decreased till 2005-06. It showed improvement in 2006-07. 


\section{Production and Sale of milk by the Milk Unions of Karnataka Milk Federation (KMF)}

As noted earlier, the organized sector has played a pivotal role in the development of dairy in Karnataka. To be more specific, the various Co-operative Milk Unions in various districts have greatly helped in dairy development by providing marketing avenues to milk produced by individual milk producers. At regional level the Milk Producers' Co-operative Societies are members of the district or union level cooperatives. The union level is responsible for milk collection, pasteurizing and processing the milk to other dairy products, packaging the milk and milk products and arranging for the sale of the final product. Marketing of milk and milk products to regional urban markets are also conducted on regional basis.

In addition to being the marketing and distribution arm of the Unions, Milk federation plays the role of a coordinator to the entire network within the State - coordinating procurement requirements with other Federations (in other states), determining the best production allocation for its product mix from amongst its Unions and managing inter-dairy movements.

Table 5

Union Wise Average Procurement of Milk during 2000-01 -2006-07

(lakh kilograms/day)

\begin{tabular}{|c|c|c|c|c|c|c|c|c|}
\hline MILK UNIONS & $2000-01$ & 2001-02 & $2002-03$ & 2003-04 & $\begin{array}{c}2004-05 \\
* \quad *\end{array}$ & $2005-06$ & 2006-07 & $\begin{array}{l}\text { Growth } \\
\text { Rate(\%) }\end{array}$ \\
\hline Bangalore & 5.33 & 5.47 & 5.58 & $594 / 5$ & 13 & 8.06 & 7.58 & 3.14 \\
\hline \multirow[t]{2}{*}{ Kolar } & 4.97 & 5.38 & 5.58 & $5.65,10^{\circ}$ & 6.56 & 6.54 & 6.31 & 1.91 \\
\hline & & & \multicolumn{3}{|c|}{ MEDIUM DC } & & & \\
\hline Mysore & 1.24 & 1.47 & 1.61 & 1.69 & 1.88 & 2 & 2.06 & 3.49 \\
\hline Mandya & 1.51 & 1.67 & 1.9 & 2.12 & 2.71 & 3.08 & 3.11 & 5.71 \\
\hline Hassan & 1.04 & 1.17 & 1.32 & 1.46 & 2.16 & 2.31 & 2.4 & 6.71 \\
\hline Tumkur & 0.86 & 1.07 & 1.34 & 1.25 & 1.55 & 1.82 & 1.9 & 5.47 \\
\hline Dakshina Kannada & 0.9 & 1.06 & 1.2 & 1.25 & 1.43 & 1.76 & 1.98 & 5.39 \\
\hline \multirow[t]{2}{*}{ Shimoga } & 1.21 & 1.46 & 1.56 & 1.32 & 1.5 & 1.6 & 1.49 & 1.16 \\
\hline & & & \multicolumn{3}{|c|}{ SMALL } & & & \\
\hline Dharwad & 0.59 & 0.63 & 0.61 & 0.57 & 0.67 & 0.84 & 0.74 & 2.03 \\
\hline Belgaum & 0.52 & 0.45 & 0.47 & 0.47 & 0.53 & 0.57 & 0.53 & 0.97 \\
\hline Bijapur & 0.2 & 0.19 & 0.16 & 0.16 & 0.24 & 0.31 & 0.36 & 4.91 \\
\hline Gulbarga & 0.18 & 0.19 & 0.19 & 0.18 & 0.21 & 0.24 & 0.24 & 1.95 \\
\hline RaichurBellary & 0.35 & 0.35 & 0.38 & 0.37 & 0.42 & 0.51 & 0.52 & 3.12 \\
\hline Total & 18.91 & 20.56 & 21.89 & 22.43 & 26.99 & 29.64 & 29.24 & 3.40 \\
\hline
\end{tabular}

Source: Compiled from the records of KMF, Bangalore 
Based on the above analysis, it is hereby noticed that all the small milk unions are in the northern part of Karnataka, namely Dharwad, Belgaum, Bijapur, Gulbarga and Raichur Bellary milk unions. The larger milk unions are Bangalore and Kolar located in the southern part of the State are in close proximity to each other.

Data on Union wise milk sales over the years is incorporated in Table 6.

Table 6

Union Wise Average Sales of Milk during 2000-01-2006-07(lakh kilograms/day)

\begin{tabular}{|c|c|c|c|c|c|c|c|c|}
\hline Milk Unions & 2000-01 & 2001-02 & 2002-03 & 2003-04 & 2004-05 & 2005-06 & 2006-07 & Growth Rate \\
\hline & & & & LARGE & & & & \\
\hline \multirow[t]{2}{*}{ Bangalore } & 4.35 & 4.38 & 4.34 & 4.49 & 4.83 & 5.26 & 5.8 & 4.89 \\
\hline & & & \multicolumn{3}{|c|}{ MEDIUM } & & & \\
\hline Kolar & 0.88 & 0.91 & 0.83 & 0.9 & 1.00 & 1.14 & 1.35 & 7.10 \\
\hline Mysore & 1.09 & 1.05 & 0.93 & 0.99 & 1.06 & 1.11 & 1.21 & 2.00 \\
\hline Mandya & 0.98 & 1.03 & 1.04 & 1.14 & $1.25 *$ & 1.36 & 1.49 & 7.39 \\
\hline Tumkur & 0.82 & 0.84 & 0.79 & & & 0.92 & 1.03 & 3.37 \\
\hline DakshinaKannada & 1.11 & 1.21 & 1.26 & & $= \pm 52$ & 1.68 & 1.87 & 8.98 \\
\hline Hassan & 0.72 & 0.71 & 0.65 & & 0.64 & 0.71 & 0.79 & 0.94 \\
\hline \multirow[t]{2}{*}{ Shimoga } & 1.08 & 1.11 & 0.96 & 0.93 & 0.88 & 0.88 & 0.91 & -3.73 \\
\hline & & & \multicolumn{3}{|c|}{$\begin{array}{l}1971 \text { to } 2011 \\
\text { SMALL }\end{array}$} & & & \\
\hline Bijapur & 0.26 & 0.23 & 0.27 & 0.28 & 0.26 & 0.28 & 0.37 & 5.18 \\
\hline Gulbarga & 0.28 & 0.27 & 0.27 & 0.3 & 0.3 & 0.32 & 0.41 & 5.84 \\
\hline Dharwad & 0.58 & 0.54 & 0.54 & 0.55 & 0.51 & 0.54 & 0.53 & -1.16 \\
\hline RaichurBellary & 0.35 & 0.36 & 0.36 & 0.4 & 0.4 & 0.43 & 0.54 & 6.49 \\
\hline Belgaum & 0.47 & 0.47 & 0.45 & 0.44 & 0.44 & 0.43 & 0.57 & 1.36 \\
\hline Total & 12.97 & 13.11 & 12.69 & 13.26 & 13.93 & 15.06 & 16.87 & 4.23 \\
\hline
\end{tabular}

Source: Compiled from the records of KMF, Bangalore

It could be seen from the Table 6 that there has been a rising trend in milk sales by different Unions over the years even though there are some fluctuations. This is in contrast to findings obtained from various tables analysed so far. 
In the year 2000-01, out of the total milk sales of 12.97 lakh litres per day by all Unions, Bangalore Union accounted for 4.35 lakh litres per day followed by Dakshina Kannada Milk union at 1.11 lakh litres of milk sales per day and Mysore milk union at 1.09 lakh litres of milk sales per day. These three unions accounted for about $\mathbf{5 0 . 5}$ percent of total milk sales in 2000-01.

In 2006-07, Bangalore Union topped the list with 5.8 lakh litres per day, followed by Dakshina Kannada Union at 1.87 lakh litres per day and Mandya Union at 1.49 lakh litres of milk sales per day. These three unions accounted for about $\mathbf{5 4 . 3}$ percent of total milk sales in 2006-07.
Taking into account the growth rate in terms of milk sales, the following observations were made. Dakshina Kannada Milk Union (8.98 \%) witnessed the maximum growth rate in terms of milk sales, followed by closely followed by Mandya milk Union (7.39\%) over the period 2000-01 to 2006-07. Shimoga milk union recorded the minimum increase $(-3.73 \%)$.

It is not enough to find the quantity of milk produced and procured by the milk unions. It becomes necessary to identify the proportion of milk sold of the total milk procured by the milk unions. This is given by Table 7 .

\begin{tabular}{|l|l|l|l|l|l|l|l|c|}
\hline No. & Milk unions & $\mathbf{2 0 0 0 - 0 1}$ & $\mathbf{2 0 0 1 - 0 2}$ & $\mathbf{2 0 0 2 - 0 3}$ & $\mathbf{2 0 0 3 - 0 4}$ & $\mathbf{2 0 0 4 - 0 5}$ & $\mathbf{2 0 0 5 - 0 6}$ & $\mathbf{2 0 0 6 - 0 7}$ \\
\hline 1 & Bangalore & 81.43 & 80.07 & 77.78 & 75.42 & 67.74 & 65.26 & 76.52 \\
\hline 2 & Kolar & 17.51 & 16.91 & 14.87 & 15.93 & +15.24 & 17.43 & 21.39 \\
\hline 3 & Mysore & 87.1 & 71.43 & 57.76 & 58.58 & 56.38 & 55.5 & 58.74 \\
\hline 4 & Mandya & 64.9 & 61.68 & 54.74 & 53.77 & 46.13 & 44.16 & 47.91 \\
\hline 5 & Tumkur & 95.35 & 78.5 & 58.21 & 63.2 & 53.55 & 50.55 & 54.21 \\
\hline 6 & Hassan & 69.23 & 60.68 & 49.24 & 43.84 & 29.63 & 30.74 & 32.5 \\
\hline 7 & Dharwad & 98.31 & 84.13 & 88.52 & 96.49 & 76.12 & 65.06 & 71.62 \\
\hline 8 & Belgaum & 90.38 & 104.44 & 95.74 & 93.62 & 83.02 & 76.79 & 107.55 \\
\hline 9 & Bijapur & 125.00 & 121.05 & 168.75 & 175 & 108.33 & 90.32 & 100 \\
\hline 10 & Gulbarga & 155.56 & 136.84 & 142.11 & 166.67 & 1414.29 & 133.33 & 170.83 \\
\hline 11 & Dakshina Kannada & 123.33 & 114.15 & 105 & 112.8 & 106.29 & 95.45 & 94.44 \\
\hline 12 & Shimoga & 88.43 & 76.03 & 61.54 & 70.45 & 58.67 & 54.38 & 61.07 \\
\hline 13 & Raichur-Bellary & 97.14 & 100 & 92.11 & 108.11 & 95.24 & 84.31 & 103.85 \\
\hline & Total & 68.27 & 63.62 & 57.91 & 59.1 & 61.49 & 50.79 & 57.65 \\
\hline
\end{tabular}

Source: Compiled from the records of KMF, Bangalore 
Sales as a percentage of Milk Procured, 2001-02-2006-07

Table 7 reveals the following observations. During 2000-01, milk sold by Bijapur, Gulbarga and Dakshina Kannada Milk union, was more than the milk procured by these unions. This was possible due to inter dairy milk transfers among the milk unions and reduction in the fat content of milk. During 2006-07, Gulbarga retained itself among the top sellers of the milk procured followed by Belgaum and Raichur-Bellary Milk Unions. Kolar and Mandya Milk unions continued to sell less liquid milk of the milk procured because these unions convert the milk into ghee, skimmed milk powder and other milk products.

\section{Conclusion}

This article shows the pattern of milk production in India and Karnataka. Stagnant until 1970, India's milk production began to rise, crossing 80 million tonnes in 2000-01, 90 million tonne in 2004-05, and crossed 100 million- tonne in 2007. Among different states; Uttar Pradesh ranked high in milk production followed by Punjab, Rajasthan and Andhra Pradesh. The top ten milk producing states account for 80.9 percent of the total milk production in India. Karnataka with a share of 4.4 per cent occupied the $10^{\text {th }}$ position in India. About 47 percent of India's milk production comes from northern India, with Uttar Pradesh contributing 17.9 million-tonne. Karnataka contributes to about 4.08 million-tonne of milk. Punjab achieved a high degree of per capita milk availability with 898 grams per day, while Mizoram is cursed at the bottom with per capita milk availability of only 44 grams per day. The per capita availability of milk in Karnataka decreased from 233 grams per day in 2000-2001 to 197 grams per day in 2006-07.

Milk production in Karnataka has been declining after the Operation Flood programme ended in 1997 till 2003-04. Hassan Milk Union (6.71\%) witnessed the maximum growth rate in terms of milk procurement. followed by Mandya milk Union (5.71\%), and Tumkur
Milk Union (5.47\%). Belgaum (0.97\%) and Shimoga Milk Union (1.16\%) recorded the minimum growth rate over the period 2000-01 to 2006-07. Dakshina Kannada Milk Union (8.98 \%) witnessed the maximum growth rate in terms of milk sales, followed by closely followed by Mandya milk Union (7.39 \%) over the period 2000-01 to 2006-07. Shimoga milk union recorded the minimum increase $(-3.73 \%)$. Three milk unions, Bangalore, Dakshina Kannada and Mandya accounted for about 54.3 percent of total milk sales in 2006-07.

The Indian dairy industry has been changing rapidly owing to competitive pressures since the early 1980s. Basic operations in most dairies are being continuously improved. There is a need to deal with an application of a benchmarking process in the dairy industry. An overall organisational strategy must be developed including some basic choices for competing. In doing so, priorities have been established among the following four characteristics,

up onamely, production, cost efficiency, dependability (relíable, timely delivery to customers) and flexibility. 焦e ocus on economic efficiency at the production core of the milk unions is the basis of scientific Galomanagement. The integration of the milk production VE $\triangle$ with the processing sector (Milk Unions) is an important component to bring about structural trânsformation among the milk unions.

\section{References}

- P.R. Gupta, Dairy India, $6^{\text {th }}$ edition, New Delhi; 2007, p.116.

- Times News Network, Times of India, Feb 11,2010

- Compiled records of KMF, Bangalore Statistical abstract of Karnataka, Directorate of Economics and Statistics, 2006-07, Government of Karnataka.

- Published records of State/UT Animal Husbandry Departments, Dairy development, Government of India. 